Canadian

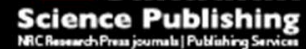

Canadian Journal of Microbiology Revue canadienne de de microbiologie

\title{
VIRULENCE AND TOXIGENICITY OF COAGULASE-NEGATIVE STAPHYLOCOCCI FROM NIGERIAN TRADITIONAL FERMENTED FOODS
}

\begin{tabular}{|r|l|}
\hline Journal: & Canadian Journal of Microbiology \\
\hline Manuscript ID & cjm-2015-0752.R3 \\
\hline Manuscript Type: & Article \\
\hline Date Submitted by the Author: & 04-Mar-2016 \\
\hline Complete List of Authors: & $\begin{array}{l}\text { Fowoyo, Patience; Salem University } \\
\text { Ogunbanwo, Samuel; University of Ibadan }\end{array}$ \\
\hline Keyword: & $\begin{array}{l}\text { virulence, coagulase-negative staphylococci, biofilm, enterotoxins, } \\
\text { exoenzymes }\end{array}$ \\
\hline
\end{tabular}

SCHOLARONE ${ }^{m}$

Manuscripts 


\title{
VIRULENCE AND TOXIGENICITY OF COAGULASE-NEGATIVE STAPHYLOCOCCI IN NIGERIAN TRADITIONAL FERMENTED FOODS
}

\author{
Fowoyo P.T. \\ Ogunbanwo, S.T. \\ Biosciences Department, Salem University, P.M.B. 1060, Lokoja, Nigeria. \\ Microbiology Department, University of Ibadan, Ibadan, Nigeria. \\ seunpt@yahoo.com, 08079550224
}




\begin{abstract}
The incidence of coagulase-negative staphylococci may render food unsafe as the clinical isolates have been reported to exude virulent traits. A total of $255 \mathrm{CoNS}$ isolates from six traditional fermented foods (nono, kunu, wara, iru, ogi and kindirmo) from North Central Nigeria identified as S. epidermidis, S. simulans, S. xylosus, S. kloosii and S. caprae were investigated for virulence traits. The stains were examined for biofilm formation, production of hyaluronidase, DNAse, TNAse, haemolysins and superantigenic toxins (SEA, SEB, SEC, SED and TSST-1) using standard and genotypic methods. The analysis of virulence factors revealed the production of slime in 200 (78.4\%), $\alpha$ - haemolysin $136(53.3 \%)$, $\beta$-haemolysin 43 (16.9\%), DNAse 199 (78.0\%), TNAse 29 (11.4\%) and hyaluronidase 125 (49.0\%), TSST-1 119 (46.7\%) and enterotoxin producing isolates: SEA, SEB, SEC and SED (61 (23.9\%), 19 (7.5\%), 9 (3.5\%) and $8(3.1 \%)$ respectively). PCR analysis detected tsst-1, sea, seb and sec genes. The ability of these microorganisms to exhibit virulence evokes the potential to cause disease especially under determinate conditions or in immune-compromised patients. The occurrence of CoNS in food should not be ignored nor their pathogenic potential considered as insignificant rather safety measures should be taken to reduce or totally eliminate their occurrence in foods.
\end{abstract}

Keywords: Traditional fermented foods, Coagulase-negative staphylococci (CoNS), Biofilm, haemolysin, Exoenzyme, Enterotoxins.

\title{
Introduction
}

Traditional fermented foods comprise the highest proportion of people's diet in sub-Saharan Africa. Most of these foods are prepared from cereal grains (maize, sorghum, millet), root tubers (cassava), legume and other seeds (African locust bean, African oil bean, cotton and other melon seeds etc.) and to a lesser extent, animal milk. Some common Nigerian fermented foods 
include okpehe, nono, ogi, kunu, wara, kindirmo and iru. Nono, wara and kindirmo are produced using raw cow milk. Nono is a Nigerian locally fermented milk product similar to sour yoghurt commonly prepared by nomadic Fulanis (Yahuza, 2001) while Kindirmo is a traditional, viscous full-fat fermented orpartially skimmed cow milk product (Igwe and Yakubu 2000). Wara is a white, soft, un-ripened cheese made by the addition of vegetable rennet made from a native plant extract (Calotropis procera) or pawpaw (Carica papaya) to the non-pasteurized whole milk from cattle which coagulates the milk (Adeyemi and Umar 1994). Kunu is a non-alcoholic fermented beverage widely consumed in Northern part of Nigeria produced by fermentation of cereals such as millet, sorghum or a combination of both. Iru is one of the most important food condiments in Nigeria and it is prepared from the seeds of African locust beans (Parkia biglobosa) (Achi, 2005). These indigenous foods are locally prepared in small scale in urban, peri-urban and in the village homes and their quality depends on the skills of the household occupant as inherited over the years (Chelule et al. 2010). The uncontrolled, naturally initiated fermentation processes expectedly yield products of inconsistent quality attributes, and, in some instances, the fermenting microorganisms may be out-competed by other opportunistic microbes of the fermenting matrix, thereby resulting into a sub-optimal fermentation. The prevalent food-borne diseases in the sub-region could be traced to the establishment of food borne pathogens that may have gained entry as contaminants or associated microorganisms of uncontrolled fermentation processes.

Coagulase-negative staphylococci were long considered non-pathogenic and having few virulence factors however, this notion has been corrected as most studies have shown that just like the known pathogenic $S$. aureus, they also possess virulent factors and have been implicated as pathogens of diverse diseases (Akinkunmi and Lamikanra 2012). Staphylococci expresses many potential virulence factors such as surface proteins that promote colonization of host tissues, invasins that promote bacterial spread in tissues (leukocidin, kinases, hyaluronidase), surface factors that inhibit phagocytic engulfment (capsule, Protein A), biochemical properties that enhance their survival in phagocytes (carotenoids, catalase production), immunological disguises (Protein A, coagulase, clotting factor); and membrane-damaging toxins that lyse eukaryotic cell membranes (hemolysins, leukotoxin, leukocidin, exotoxins that damage host 
tissues (Proctor 2000). Slime production in CoNS has been noted to be an important factor in the pathogenesis of infections since 1972 (Huebner and Goldmann 1999; Akinkunmi and Lamikanra 2012). The slime or biofilm formation is the most important virulence factor of coagulase negative staphylococci since it enables their attachment and persistence on foreign mater and also protects them from the action of antibiotics and the immune system (Mack et al. 2007). Staphylococcus secrete proteins or toxins such as alpha $(\alpha), \operatorname{beta}(\beta), \operatorname{gamma}(\gamma)$, and $\operatorname{delta}(\delta)$ haemolysins, leukocidin, exfoliative toxins A and B, toxic shock syndrome toxin-1 (TSST-1) and the staphylococcal enterotoxins (SE) (Ayepola 2012). Staphylococcal toxins can be divided into two groups according to their ability to lyse cells and they are hemolysins or cytotoxins and superantigenic toxins (Freer and Arbuthnott 1983, Ayepola 2012). Staphylococci produce a wide variety of exoenzymes most of them during the post exponential growth phase. These proteins degrade the host tissue to nutrients required for the growth of bacteria, and/or allow the bacteria to penetrate deeper into the host tissue or hydrolyze nucleic acids such as hyaluronidase, thermonuclease (TNAse) and deoxyribonuclease (DNAse). Enterotoxins are also considered to be the major cause of food poisoning. They are associated with a form of gastroenteritis manifesting clinically with vomiting or emesis, with or without diarrhea, resulting from the ingestion of one or more staphylococcal enterotoxins contained in food that has been contaminated with these bacteria. Toxic Shock Syndrome Toxin -1 (TSST-1) is an extracellular superantigen toxin produced by some isolates of Staphylococcus. TSST-1 is one of the causes of Toxic Shock Syndrome (TSS). Toxic Shock Syndrome is rare but can be a serious consequence of a burn wound infection and other staphylococcal infections. It is a disease that affects multiple organs and may be fatal (Edwards-Jones et al. 2000). It is characterised by rapid fever, arterial hypotension, diffuse cutaneous rash, circulatory failure, vomiting, diarrhoea, myalgia, epidermis scaling, hypo-albuminemia and organ failure (multiple organ dysfunction syndrome - MODS) (Javid Khojasteh and Foster 2011). If the symptoms or infection are not properly treated soon after the onset of symptoms, a fatal shock may develop within $24 \mathrm{~h}$. This study is therefore aimed at determining the virulence potential of CoNS associated with Nigerian traditional fermented foods. 


\section{Materials and Methods}

\section{Test Isolates}

A total of 255 CoNS species comprising of $S$. epidermidis (128), $S$. simulans (50), $S$. xylosus (36), S. kloosii (28) and S. caprae (13) isolated from 324 samples consisting of six (6) traditional fermented foods (kunu, nono, wara, kindirmo, ogi and iru) from North Central Nigeria were used for this study. The CoNS species were phenotypically characterised using the identification keys by Kloos and Schleifer (1986) and molecularly characterised employing 16S rRNA sequencing according to the methods of Kim et al. (2008).

\section{Slime or Biofilm Formation in Test Isolates}

The Congo Red Agar (CRA) method developed by Freeman (1989) was used. The Congo red stain was prepared as a concentrated aqueous solution and autoclaved separately at $121^{\circ} \mathrm{C}$ for 15 min. The agar was weighed and dissolved in $1000 \mathrm{ml}$ of sterile distilled water and sterilized at $121^{\circ} \mathrm{C}$ for $15 \mathrm{~min}$. The agar was allowed to cool to $55^{\circ} \mathrm{C}$ and mixed with the sterile Congo red stain. The agar was poured into plates, allowed to solidify and then inoculated with the test isolate and incubated aerobically at $37^{\circ} \mathrm{C}$ for $24 \mathrm{~h}$.

Isolates which produced black colonies with dry crystalline consistency were regarded as slime positive, whereas those showing pink colonies were labelled as slime negative.

\section{Thermonuclease (TNAse) Test}

The ability to produce TNAse was determined using the method described by Hawkey and Lewis (1989). For the detection of TNAse activity, thermonuclease agar (Thermo Scientific, Milan, Italy) was prepared and poured into plastic Petri dishes. The test isolates were streaked on the agar and incubated at $100^{\circ} \mathrm{C}$ for $10 \mathrm{~min}$. The formation of pink colonies indicates the presence of thermostable nuclease.

\section{DNAse test}

The method of Deighton et al. (1988) was employed. This test was carried out by using commercially available DNAse agar (Oxoid, Wesel, Germany). Spot inoculation with the test 
isolates was done on the DNAse agar and incubated at $37^{\circ} \mathrm{C}$ for 4 days. After incubation, $1 \mathrm{~N}$ $\mathrm{HCl}$ was poured on the agar. A zone of clearance around the bacterial growth was interpreted as a positive result.

\section{Haemolysin Production in Test Isolates}

The method of Akinjogunla et al. (2014) was employed. The haemolytic activities of the isolates were identified by the presence of diffuse ( $\alpha$-haemolysis) or clear ( $\beta$-haemolysis) halos around the colonies. A colony of each of the bacterial isolates was sub-cultured onto freshly prepared blood agar (nutrient agar containing human blood) plates incubated at $37^{\circ} \mathrm{C}$ for $24 \mathrm{~h}$, after which the colonies were examined for haemolytic activity.

\section{Hyaluronidase Production in Test Isolates}

The presence of hyluronidase was evaluated on Brain Heart Infusion agar (BHI, Oxoid, Wesel, Germany) containing hyaluronic acid; $0.4 \mathrm{mg} / \mathrm{ml}$ (Thermoscientific, Italy) as described by Makris et al. (2004). The hyaluronidase agar was inoculated with the test isolate and incubated at $37^{\circ} \mathrm{C}$ for $24 \mathrm{~h}$, after which the plates were covered with cetylpyridinium chloride and a positive result was indicated by the formation of a transparent halo around the colonies.

\section{Detection of Enterotoxigenic CoNS Species from Fermented Food Samples Phenotypic Detection of Toxic Shock Syndrome Toxin (TSST-1)}

The method of Wongboot et al. (2013) was employed. Toxic shock syndrome toxin 1 (TSST-1) was detected by the reversed passive latex agglutination (RPLA) assay as described by Shingaki et al. (1981). The TSST-1 superantigenic toxins were detected using commercial standardized RPLA test kit (SET- TST-RPLA-TD0940) (Oxoid, Wesel, Germany) according to the manufacturer's instructions. The test isolates were grown in brain heart infusion broth and incubated at $37^{\circ} \mathrm{C}$ for $18-24 \mathrm{~h}$ in an incubator shaker. The overnight culture was centrifuged at $900 \mathrm{x}$ g for $20 \mathrm{~min}$ at $4^{\circ} \mathrm{C}$. Then, a $25 \mu \mathrm{l}$ aliquot of supernatant was mixed with $25 \mu 1$ of the latex suspension of each superantigenic toxin control in a V-well microtiter plate. The presence of agglutination resulting in the formation of a lattice structure indicates a positive result. 


\section{Phenotypic Detection of Enterotoxigenic (SE) CoNS Isolates}

The method of Shingaki et al. (1981) was employed using SET - RPLA toxin detection kit (TD0900) (Oxoid, Wesel, Germany). The test isolate was inoculated into tryptone soya broth and incubated at $37^{\circ} \mathrm{C}$ for $18-24 \mathrm{~h}$ in an incubator shaker. The culture broth was centrifuged at 900 $\mathrm{x} g$ for $20 \mathrm{~min}$ in a cold centrifuge at $4^{\circ} \mathrm{C}$. The supernatant was filtered with a $0.45 \mu \mathrm{m}$ membrane filter paper. The filtrate was used for the qualitative detection of the staphylococcal enterotoxins (SE). V-shaped microplate wells were inoculated with $25 \mu$ of the filtrate and $25 \mu 1$ of thoroughly shaken latex sensitized with anti-enterotoxins A, B, C and D (provided by the manufacturer). Standard toxins (provided by manufacturer in the kit from Oxoid diagnostics reagents) were used as positive controls and the occurrence of non-specific reactions was tested by the addition of $25 \mu 1$ of the supernatant to $25 \mu 1$ of the control latex. The plates were covered with a lid and placed on black cellophane, left undisturbed on a vibration free surface and incubated for $20-24 \mathrm{~h}$ at $37^{\circ} \mathrm{C}$. The results were interpreted according to the agglutination pattern described by the manufacturer. Positive reactions were classified as $(+),(++)$ and $(+++)$ while the formation of a pink bud was interpreted as a negative result.

\section{Detection of tsst-1 Gene and Staphylococcal Enterotoxin Genes (sea, seb, sec, sed) in Test Isolates}

The method by Johnson et al. (1991) was employed. Genomic DNA was isolated from $5 \mathrm{ml}$ of an $18 \mathrm{~h}$ broth culture from all the bacterial isolates. Cells were pelleted from the cultures by centrifugation at $1,000 \mathrm{x} \mathrm{g}$ for $10 \mathrm{~min}$ and re-suspended in phosphate buffered saline with $100 \mu \mathrm{g}$ of lysostaphin (Sigma) per $\mathrm{ml}$, and incubated at $37^{\circ} \mathrm{C}$ for $0.5 \mathrm{~h}$ or until viscous. Template DNA from all preparations were subsequently extracted with phenol chloroform and precipitated with ethanol. Template DNA samples were dissolved in TE buffer $(10 \mathrm{mM}$ Tris chloride-1 $\mathrm{mM}$ EDTA, $\mathrm{pH} 8.0$ ) and adjusted to a final concentration of $2 \mu \mathrm{g} / \mathrm{ml}$ with TE buffer according to $\mathrm{A}_{260}$ values. PCR was carried out in $0.5 \mathrm{ml}$ microcentrifuge tubes to which 20 pmol of each primer was added as shown in Table 1 together with 2.5 U Taq DNA polymerase (Promega), 200 $\mu \mathrm{M}$ dNTPs, $20 \mathrm{mM}$ Tris-HCl, $\mathrm{pH} 8.4,0.75 \mathrm{mM} \mathrm{MgCl}_{2}$, and $5 \mu \mathrm{L}$ DNA (total volume of 50 
$\mu \mathrm{L})$. The negative control used was water which was run in parallel with that of the DNA. Amplification was performed with an MJ Research PTC-100 thermocycler as described by Johnson et al. (1991) with some modification as proposed by Cunha et al. (2006), which consisted of a first cycle at $94^{\circ} \mathrm{C}$ for $4 \mathrm{~min}$, denaturation at $94^{\circ} \mathrm{C}$ for $2 \mathrm{~min}$ followed by annealing at $55^{\circ} \mathrm{C}$ for $1 \mathrm{~min}$ and $30 \mathrm{~s}$, and extension at $72^{\circ} \mathrm{C}$ for $1 \mathrm{~min}$ and $30 \mathrm{~s}$, followed by a second cycle of denaturation at $94^{\circ} \mathrm{C}$ for $2 \mathrm{~min}$, annealing at $53^{\circ} \mathrm{C}$ for $1 \mathrm{~min}$ and $30 \mathrm{~s}$, and extension at $72^{\circ} \mathrm{C}$ for $1 \mathrm{~min}$ and $30 \mathrm{~s}$. In the third cycle, the annealing temperature was reduced to $51^{\circ} \mathrm{C}$, followed by additional 37 cycles at $94^{\circ} \mathrm{C}$ for $2 \mathrm{~min}, 51^{\circ} \mathrm{C}$ for $1 \mathrm{~min}$ and $30 \mathrm{~s}$ and $72^{\circ} \mathrm{C}$ for $1 \mathrm{~min}$ and $30 \mathrm{~s}$. At the end of the 40 cycles, the tubes were incubated at $72^{\circ} \mathrm{C}$ for $7 \mathrm{~min}$ and stored at $4^{\circ} \mathrm{C}$. The amplified products were run on $2 \%$ agarose gels in $1 \mathrm{X}$ TBE buffer stained with ethidium bromide. The sizes of the amplified products were compared with 50- and 100-kb standards and the gels photographed under UV transillumination.

\section{Result}

The virulent attributes of the CoNS species were assessed. Biofilm formation was expressed in $78.4 \%$ of all the CoNS species. S. xylosus had the highest percentage of slime producers $(88.9 \%)$ from nono samples. S. epidermidis $(75.8 \%)$ was mostly isolated from iru and kindirmo samples. S. kloosii, S. simulans and S. caprae produced slime with the percentage occurrences of $86 \%, 67.9 \%$ and $69.2 \%$ respectively in kindirmo samples as shown in Table 2.

The CoNS species (11.4\%) produced thermonuclease (TNAse) enzyme. S. simulans (22.0\%) had the highest frequency of isolates producing thermonuclease enzyme (TNAse) with $6.0 \%$ each incidence in kindirmo, nono and wara. $7.8 \%$ ofS. epidermidis, 7\% of S. kloosii, $11.2 \%$ of $S$. xylosus and $15.0 \%$ of $S$. caprae produced TNAse enzyme with their highest occurrence in wara and kindirmo as shown in Table 3.

Table 4 shows that $S$. caprae had the highest percentage (92.3\%) of deoxyribonuclease (DNAse) producers with the highest occurrence in nono, kindirmo and wara. $75.8 \% \mathrm{~S}$.

epidermidis isolates, $82.1 \%$ S. kloosii , $77.8 \%$ S. xylosus and 78.0\% S. simulans isolates were 
found to be producers of DNAse with the highest incidence observed in iru, kindirmo,wara and kindirmo food samples respectively.

Table 5 shows the haemolytic attributes of the CoNS species. $53.3 \%$ of the isolates were $\alpha$ haemolysin producers while $16.9 \%$ of them produced $\beta$-haemolysin. All the species produced haemolysins however some isolates from ogi,kunu, kindirmo, wara and iru did not produce haemolysins. Majority of $\alpha$ - haemolysin producers belonged to S. epidermidis $(47.7 \%), S$. kloosii (57.1\%) and S. xylosus (69.4\%). S. xylosus had the highest isolates $(25.0 \%)$ producing $\beta$ haemolysin followed by S. epidermidis (21.9\%), S. caprae (23.1\%), S. simulans (3.6\%). The ability of CoNS to produce hyaluronidase was examined. $62.0 \%$ of $S$. simulans isolates produced hyaluronidase and they were the highest producers. The other species had the following occurrence; S. epidermidis (43.8\%), S. kloosii(57.1\%), S. xylosus (41.7\%) and S. caprae $(53.8 \%)$ as shown in Table 6 . The occurrence of these microorganisms was more from foods isolated from iru, kindirmo and nono.

Toxic shock syndrome toxin (TSST-1) production by CoNS species is shown in Table 7. S. epidermidis, S. simulans and S. xylosus $(42.2 \%, 42.0 \%$ and $41.7 \%$ respectively) were the predominant producers of the toxin. The occurrence of the toxin producers was remarkably high in kindirmo, wara and nono samples. The presence of the tsst-1 gene in the CoNS isolates was confirmed by PCR analysis in the same organisms as detected phenotypically. PCR analysis revealed that forty seven percent $(47.0 \%)$ of the CoNS isolates had tsst-1 gene.

The production of staphylococcal enterotoxin A, B, C and D (SEA, SEB, SEC and SED) by the CoNS species revealed that $23.9 \%$ of all the CoNS species were producers of SEA. SEA was the highest occurring toxin produced as compared to SEB (7.5\%), SEC (3.5\%) and SED (3.1\%). $S$. xylosus $(86.0 \%)$ was the predominant enterotoxin producers as shown in Table 8. PCR analysis detected sea, seb and sec genes but sed gene was not detected among the CoNS species. Kindirmo, waraand nono samples had the highest incidence of enterotoxigenic CoNS species as shown in Fig.1.

\section{Discussion}


A large percentage of the CoNS species were slime or biofilm producers. Biofilms are very fine extracellular polymeric fibrils attached to bacteria and they are a survival strategy used by bacteria in natural and industrial systems (Oliveira and Cunha, 2008). The ability of the organisms to produce biofilm isa useful marker in the pathogenicity of CoNS (Turkyilmaz and Kaya 2006; Landeta et al. 2013). Slime production may also reflect the microorganism's ability to adhere to specific host tissues and thereby produce invasive microcolonies (Gundogan and Ataol 2013; Priya et al. 2014). They can persist on metal devices, milking equipment as well as on the milker's hands which serve as a major source of staphylococcal spread (Pilipcincova et al. 2010). The production of biofilm reduces the organism's susceptibility to antimicrobials (John and Harvin 2007).

A relatively small proportion (11.4\%) of the species produced thermonuclease (TNAse). TNase hydrolyses single and double-stranded RNA and DNA at the 5' position of phosphodiester bonds by a calcium-dependent mechanism. This enzyme is known to break down or destroy nucleic acids and this also contributes to the virulence of these organisms.

Deoxyribonuclease (DNAse) was produced by a large percentage of the CoNS species isolated in this study. Lambe et al. (1990) reported that $S$. epidermidis could produce DNAse. The production of DNAse may be responsible for tissue degradation and spreading of an infection caused by these bacteria (Stepanovic et al. 2001).

Hyaluronidase production by the CoNS species was observed in this study. Hyaluronidase is an enzyme that catalyzes the hydrolysis of hyaluronic acid which cements or binds connective tissues. They are also known as spreading factor because once the tissues are broken they can easily spread in tissues and cause infection and this function also contributes to the virulent attributes of CoNS.

The predominant $\alpha$-haemolysin producers were $S$. epidermidis, $S$. simulans, $S$. kloosii and $S$. xylosus and this conforms to the work of (Azih and Enabulele 2013). The $\beta$-haemolysins were predominantly produced by $S$. epidermidis, S. xylosus and S. caprae. Damage to host cells is mediated by staphylococcal haemolysins which contributes significantly to their virulence (Turkyilmaz and Kaya 2006). 
Majority of the CoNS species produced SEA toxin than the other enterotoxins. $S$. epidermidis and $S$. caprae were the highest SEA toxin producers while S. xylosus and $S$. caprae were the predominant producers of the enterotoxin SEB, SEC and SED. SEA is known to be the most potent of the isolates and this also lends credence to their virulence (Bergdoll and Crass 1986). Nono, Kindirmo and Wara samples had the highest numbers of staphylococcal enterotoxin producers and this may be attributed to the use of unpasteurized milk for their production coupled with the unhygienic practices of the Fulanis especially in the rural areas. Staphylococcal food-borne diseases acquired from eating enterotoxin-contaminated food are the second most commonly reported types of food-borne diseases (Reyes et al. 2010).

\section{Conclusion}

The virulence of CoNS isolated from food has demonstrated how these organisms may represent hazard and behave as true pathogens in determinate conditions in particular, when the host is immune-compromised. It is therefore recommended that these organisms should not be dismissed as contaminants but rather awareness about the pathogenicity of the organism be spread. Their occurrence in food may also signal caution as regards to food safety.

\section{References}

Achi, O.K. 2005. Traditional fermented protein condiments in Nigeria. African Journal of Biotechnology, 4 (13): 1612-1621.

Adeyemi, L.A. and Umar, S. 1994. Effect of method of manufacture on quality characteristic of kunun zaki, a millet based beverage. Nigerian Food Journal, 12: $34-41$.

Akinjogunla, O. J., Ajayi, A.O. and Ekeh, N.O. 2014. Virulence factors and antibiotic resistant Staphylococcus spp from the anterior nares of apparently healthy undergraduate students in uyo. American Journal of Research Communication, 2 (11): 158 - 180.

Akinkunmi, E. O. and Lamikanra, A. 2012. Phenotypic determination of some virulence 
factors in staphylococci isolated from faecal samples of children in Ile-Ife, Nigeria. Afr. J. Biomed. Res.,15: 123 - 128.

Ayepola, O.O. 2012. Molecular characterization and antibiotic susceptibility pattern of Staphylococcus aureus isolated from clinical and environmental sources. $\mathrm{PhD}$ thesis. Covenant University, Ota, Ogun State.

Azih, A. and Enabulele, I. 2013. Species distribution and virulence factors of coagulasenegative staphylococci isolated from clinical samples from the University of Benin teaching hospital, Edo State, Nigeria. Journal of Natural Sciences Research, 3 (9):38 - 44.

Chelule, P.K., Mbongwa, H.P., Carries, S., Gqaleni, N. 2010. Lactic acid fermentation improves the quality of mahewu, a traditional South African maize-based porridge. Food Chemistry,122 (3): 656-661.

Cunha, M.L.R.S., Peresi, E., Calsolari, R.A.O. and Araújo Jr, J.P. 2006. Detection of Enterotoxins genes in coagulase-negative Staphylococci isolated from foods. Braz J Microbiol., 37: 70-74.

Deighton, M.A., Franklin, J.C., Spicer, W.J. and Balkau, B. 1988. Species identification, antibiotic sensitivity and slime production of coagulasenegative staphylococci isolated from clinical specimens. Epidemiol Infect, 101: 99-113

Edwards-Jones, V., Dawson, M. and Childs, C. 2000. A survey into Toxic Shock Syndrome (TSS) in UK burns units. Burns, 26: 323-333.

Freeman, D.J., Falkiner, F.R. and Keane, C.T. 1989. New method for detecting slime production by coagulase-negative staphylococci. Journal of Clinical Pathology, 42 (8): 872-874.

Gundogan,N. and Ataol, O. 2013. Biofilm, protease and lipase properties and antibiotic resistance profiles of staphylococci isolated from various foods. African Journal of Microbiology Research, 7 (28): 3582 - 3588. doi: 10.5897/AJMR2012.2316

Hawkey, P.M. and Lewis, D.A. 1989. Medical Bacteriology: a practical approach. IRL Press, Oxford. 
Huebner, J. and Goldmann, D.A. 1999. Coagulase-negative staphylococci: role as pathogens. Annu. Rev. Med., 50:223-236.

Igwe, E.C. and Yakubu, B. 2000. The Adamawa Dairy Industry: In: Agriculture in Adamawa State. Edited by Igwe, EC., Mishelia, S.I and Jada, MY. Parclete Publishers, Yola, Nigeria.

Javid Khojasteh, V. and Foster, H.A . 2011. Dye labelled monoclonal antibody assay for detection of Toxic Shock Syndrome Toxin -1 from Staphylococcus aureus. Iranian Journal of Microbiology, 3(4): 170-176.

John, J.F., and Harvin, A.M. 2007. History and evolution of antibiotic resistance in coagulase-negative staphylococci: Susceptibility profiles of new antistaphylococcal agents. Ther. Clin. Risk Manag. 3(6):1143-1152.

Johnson, W.M., Tyler, S.D., Ewan, E.P., Ashton, F.E., Pollard, D.R. and Rozee, K.R. 1991. Detection of genes for enterotoxins, exfoliative toxins, and toxic shock syndrome toxin 1 inStaphylococcus aureus by the polymerase chain reaction. J. Clin. Microbiol., 29: 426-430.

Kim, M., Heo, S.R., Choi, S.H., Kwon, H., Park, J.S., Seong, M.W., Lee, D.H., Park, K.U., Song, J. and Kim, E.C. 2008. Comparison of the MicroScan, VITEK 2, and Crystal GP with 16S rRNA sequencing and MicroSeq 500 v2.0 analysis for coagulase-negative staphylococci. BMC Microbiol. 8:233-2240.

Kloos, W. E. and Schleifer, K.H. 1986. Genus 4, StaphylococcusRosenbach, 1984. In: J. G. Holt, P. H. A. Sneath, N. S. Mair, and M. S. Sharpe (Eds.) Bergey's Manual of Systematic Bacteriology. Williams and Wilkins. Baltimore, MD. 2:1013-1035.

Lambe, Jr. D.W., Ferguson, K.P., Keplinger, J.L., Gemmell, C.G. and Kalbfleisch, J.H. 1990. Pathogenicity of Staphylococcus lugdunensis, Staphylococcus schleiferi, and three other coagulase-negative staphylococci in a mouse model and possible virulence factors. Can J Microbiol 36:455-463. 
Landeta, G., Curiel, J.A., Carrascosa, A.V., Munoz, R. and de las Rivas, B. 2013.

Characterization of coagulase-negative staphylococci isolated from Spanish dry cured meat products. Meat Science, 93(3):387-96. doi:

10.1016/j.meatsci.2012.09.019

Mack, D., Davies, A.P., Harris, L.G., Rohde, H., Horstkotte, M.A. and Knobloch, J.K. 2007. Microbial interactions in Staphylococcus epidermidis biofilms. Anal. Bioanal. Chem., 387: 399-408.

Makris, G., Wright, J. D., Ingham, E. and Holland, K.T. 2004. The hyaluronate lyase of Staphylococcus aureus - a virulence factor? Microbiology, 150, 2005-2013.

Oliveira, A. and Cunha, M. L. R. S. 2008. Bacterial biofilms with emphasis on coagulasenegative staphylococci. J. Venom. Anim. Toxins incl. Trop. Dis., 14 (4): 592.

Pilipcincova, I., Bhide, M., Dudrikova, E. and Travnicek, M. 2010. Genotypic characterization of coagulase negative staphylococci isolated from sheep milk in Slovakia. Acta Vet. Brno., 79: 269-275.

Proctor, R.A. 2000. Coagulase-Negative Staphylococcal Infections: A Diagnostic and Therapeutic Challenge. Clin Infect Dis., 31 (1): 31-33. doi: 10.1086/313894

Priya, R., Mythili, A., Singh, Y.R.B., Sreekumar, H., Manikandan, P., Panneerselvam, K. and Shobana, C.S. 2014. Virulence, Speciation and Antibiotic Susceptibility of Ocular Coagualase Negative Staphylococci (CoNS). J Clin Diagn Res., 8(5):

DC33-DC37. doi: 10.7860/JCDR/2014/7867.4395

Reyes, V.E., Pinchuk, I. V. and Beswick, E.J. 2010. Staphylococcal Enterotoxins. Toxins, 2: 2177-2197. doi:10.3390/toxins2082177

Shingaki, M., Kim, S.H., Jeong, H.S., Oh, H.S., Kim, R.H., Lee, J.N., Yoon, Y.C., Kim, 
Y.W., Kim, Y.H., Shin, J.H., Igarashi, H., Fujikawa, H., Ushioda, H., Terayama, T. and Sakai, S. 1981. Identification of coagulase-negative staphylococci isolated from continuous ambulatory peritoneal dialysis fluid using 16S ribosomal RNA, tuf, and soda gene sequencing. Peritoneal Dialysis International, 31: 340-346. doi: $10.3747 /$ pdi.2010.00073

Stepanovic', S., Vukovic' D., Trajkovic,' V., Samardz`ic', T., C'upic', M. and S־vabic' Vlahovic', M. 2001. Possible virulence factors of Staphylococcus sciuri. FEMS Microbiol. Lett., 199: 47-53.

Turkyilmaz, S. and Kaya, O. 2006: Determination of some virulence factors in Staphylococcus spp. isolated from various clinical samples. Turkish Journal of Veterinary Animal Science, 30: 127 -132.

Wongboot, W., Chomvarin, C. and Engchanil, C. 2013. Multiplex PCR for detection of superantigenic toxin genes in methicillin-sensitive and methicillinresistant Staphylococcus aureusisolated from patients and carriers of a hospital in northeast Thailand. Southeast Asian J Trop Med Public Health, 44 (4): 660-71.

Yahuza, M. L. 2001. Smallholder dairy production and marketing constraints in Nigeria. In: Rangnekar D and Thorpe W Editors. Smallholder dairy production and marketing - Opportunities and Constraints. Proceedings of a South-South workshop held at National DairyDevelopment board (NDDB), Anand, India, 1316 March 2001 and ILRI (International Livestock Research Institute) Nairobi, Kenya. 
Table 1: Primers used in this Study

\begin{tabular}{llcc}
\hline Primers & 5' to 3' nucleotide sequence & Target & $\begin{array}{c}\text { Amplicon Size } \\
\text { (bp) }\end{array}$ \\
\hline$t$ sst- $1 f$ & ATG GCA GCA TCA GCT TGA TA & TSST-1 & 350 \\
tsst-1r & TTT CCA ATA ACC ACC CGT TT & TSST-1 & 350 \\
seal & TTG GAA ACG GTT AAA ACG AA & Enterotoxin A & 120 \\
sea 2 & GAA CCT TCC CAT CAA AAA CA & Enterotoxin A & 120 \\
sebl & TCG CAT CAA ACT GAC AAA CG & Enterotoxin B & 478 \\
seb2 & GCA GGT ACT CTA TAA GTG CC & Enterotoxin B & 478 \\
secl & GAC ATA AAA GCT AGG AAT TT & Enterotoxin C & 257 \\
sec2 & AAA TCG GAT TAA CAT TAT CC & Enterotoxin C & 257 \\
sed 1 & CTA GTT TGG TAA TAT CTC CT & Enterotoxin D & 317 \\
sed2 & TAA TGC TAT ATC TTA TAG GG & Enterotoxin D & 317 \\
\hline Source: John TAT
\end{tabular}

Source: Johnson et al., 1991 
Table 2: Frequency of Slime Producing Coagulase-Negative Staphylococci in Fermented Food Samples

\begin{tabular}{|c|c|c|c|c|c|}
\hline \multirow[b]{2}{*}{$\begin{array}{l}\text { Food } \\
\text { Samples }\end{array}$} & \multicolumn{5}{|c|}{ CoNS Species } \\
\hline & $\begin{array}{l}\text { Staphylococcus } \\
\text { epidermidis }\end{array}$ & $\begin{array}{l}\text { Staphylococcus } \\
\text { kloosii }\end{array}$ & $\begin{array}{l}\text { Staphylococcus } \\
\text { xylosus }\end{array}$ & $\begin{array}{l}\text { Staphylococcus } \\
\text { simulans }\end{array}$ & $\begin{array}{l}\text { Staphylococcus } \\
\text { caprae }\end{array}$ \\
\hline & $128^{\mathrm{a}}(\%)$ & $28^{\mathrm{a}}(\%)$ & $36^{\mathrm{a}}(\%)$ & $50^{\mathrm{a}}(\%)$ & $13^{\mathrm{a}}(\%)$ \\
\hline Nono & $10(7.8)$ & $4(14.3)$ & $10(27.8)$ & $10(20.0)$ & $3(23.1)$ \\
\hline Iru & $25(19.5)$ & $5(17.9)$ & $2(5.6)$ & $7(14.0)$ & $0(0)$ \\
\hline Ogi & $18(14.1)$ & $0(0)$ & $0(0)$ & $6(12.0)$ & $0(0)$ \\
\hline Kunu & $15(11.7)$ & $1(3.6)$ & $0(0)$ & $2(4)$ & $0(0)$ \\
\hline Kindirmo & $20(15.6)$ & $7(25.0)$ & $9(25.0)$ & $16(32)$ & $4(30.8)$ \\
\hline Wara & $9(7.0)$ & $2(7.1)$ & $11(30.6)$ & $2(4.0)$ & $2(15.4)$ \\
\hline Total & $97(75.8)$ & $19(67.9)$ & $32(88.9)$ & $43(86.0)$ & $9(69.2)$ \\
\hline
\end{tabular}

a: total number of CoNS species 
Table 3: Frequency of TNAse producing Coagulase-Negative Staphylococci in Fermented Food Samples

\begin{tabular}{|c|c|c|c|c|c|}
\hline \multirow[b]{2}{*}{ Food Samples } & \multicolumn{5}{|c|}{ CoNS Species } \\
\hline & $\begin{array}{c}\text { Staphylococcus } \\
\text { epidermidis } \\
1^{128^{\mathrm{a}}(\%)}\end{array}$ & $\begin{array}{l}\text { Staphylococcus } \\
\text { kloosii } \\
\qquad \mathbf{2 8}^{\mathrm{a}}(\%)\end{array}$ & $\begin{array}{l}\text { Staphylococcus } \\
\text { xylosus } \\
\qquad \mathbf{3 6}^{\mathbf{a}}(\%)\end{array}$ & $\begin{array}{l}\text { Staphylococcus } \\
\text { simulans } \\
\qquad 5^{\mathrm{a}}(\%)\end{array}$ & $\begin{array}{l}\text { Staphylococcus } \\
\text { caprae } \\
\qquad 13^{\mathrm{a}}(\%)\end{array}$ \\
\hline Nono & $2(1.6)$ & $1(3.6)$ & $1(2.8)$ & $3(6.0)$ & $1(7.7)$ \\
\hline Iru & $1(0.8)$ & $0(0)$ & $0(0)$ & $1(2.0)$ & $0(0)$ \\
\hline Ogi & $0(0)$ & $0(0)$ & $0(0)$ & $0(0)$ & $0(0)$ \\
\hline Kunu & $0(0)$ & $0(0)$ & $0(0)$ & $1(2.0)$ & $0(0)$ \\
\hline Kindirmo & $3(2.3)$ & $0(0)$ & $2(5.6)$ & $3(6.0)$ & $1(7.7)$ \\
\hline Wara & $4(3.1)$ & $1(3.6)$ & $1(2.8)$ & $3(6.0)$ & $0(0)$ \\
\hline Total & $10(7.8)$ & $2(7.1)$ & $4(11.2)$ & $11(22.0)$ & $2(15.4)$ \\
\hline
\end{tabular}

a: total number of CoNS species 
Table 4: Frequency of DNAse Producing Coagulase- Negative Staphylococci Species from Fermented Food Samples

\section{CoNS Species}

\begin{tabular}{|c|c|c|c|c|c|}
\hline $\begin{array}{l}\text { Food } \\
\text { Samples }\end{array}$ & $\begin{array}{l}\text { Staphylococcus } \\
\text { epidermidis } \\
128^{\mathrm{a}}(\%)\end{array}$ & $\begin{array}{l}\text { Staphylococcus } \\
\text { kloosii } \\
28^{\mathrm{a}}(\%)\end{array}$ & $\begin{array}{l}\text { Staphylococcus } \\
\text { xylosus } \\
36^{\mathbf{a}}(\%)\end{array}$ & $\begin{array}{l}\text { Staphylococcus } \\
\text { simulans } \\
50^{\mathrm{a}}(\%)\end{array}$ & $\begin{array}{l}\text { Staphylococcus } \\
\text { caprae } \\
13^{\mathrm{a}}(\%)\end{array}$ \\
\hline Nono & $10(7.8)$ & $5(17.9)$ & $6(16.7)$ & $8(16.0)$ & $4(30.8)$ \\
\hline Iru & $30(23.4)$ & $6(21.4)$ & $2(5.6)$ & $8(16.0)$ & $0(0)$ \\
\hline Ogi & $16(12.5)$ & $0(0)$ & $0(0)$ & $4(8.0)$ & $0(0)$ \\
\hline Kunu & $19(14.8)$ & $2(7.1)$ & $0(0)$ & $2(4.0)$ & $0(0)$ \\
\hline Kindirmo & $12(9.4)$ & $8(28.6)$ & $10(27.8)$ & $12(24.0)$ & $4(30.8)$ \\
\hline Wara & $10(7.8)$ & $2(7.1)$ & $10(27.8)$ & $5(8.0)$ & $4(30.8)$ \\
\hline Total & $97(75.8)$ & $23(82.1)$ & $28(77.8)$ & $39(78.0)$ & $12(92.3)$ \\
\hline
\end{tabular}

${ }^{a}:$ total number of CoNS species 
Table 5: Frequency of Haemolysin Producing Coagulase-Negative Staphylococci in Fermented Food Samples

\begin{tabular}{|c|c|c|c|c|c|c|c|c|c|c|}
\hline \multirow{4}{*}{$\begin{array}{l}\text { Food } \\
\text { Samples }\end{array}$} & \multirow{2}{*}{\multicolumn{2}{|c|}{$\begin{array}{c}\text { Staphylococcus } \\
\text { epidermidis }\end{array}$}} & \multirow{2}{*}{\multicolumn{2}{|c|}{$\begin{array}{c}\text { Staphylococcus } \\
\text { kloosii }\end{array}$}} & \multirow{2}{*}{\multicolumn{2}{|c|}{$\begin{array}{c}\text { Staphylococcus } \\
\text { xylosus }\end{array}$}} & \multirow{2}{*}{\multicolumn{2}{|c|}{$\begin{array}{c}\text { Staphylococcus } \\
\text { simulans }\end{array}$}} & \multirow{2}{*}{\multicolumn{2}{|c|}{$\begin{array}{c}\text { Staphylococcus } \\
\text { caprae }\end{array}$}} \\
\hline & & & & & & & & & & \\
\hline & \multicolumn{2}{|c|}{$128^{\mathrm{a}}(\%)$} & \multicolumn{2}{|c|}{$28^{\mathrm{a}}(\%)$} & \multicolumn{2}{|c|}{$36^{\mathrm{a}}(\%)$} & \multicolumn{2}{|c|}{$50^{\mathrm{a}}(\%)$} & \multicolumn{2}{|c|}{$13^{\mathrm{a}}(\%)$} \\
\hline & $\underline{\alpha}$ & $\beta$ & $\alpha$ & $\beta$ & $\alpha$ & $\beta$ & $\alpha$ & $\beta$ & $\alpha$ & $\beta$ \\
\hline Nono & $5(3.9)$ & $1(0.8)$ & $5(17.9)$ & $0(0)$ & 11(30.6) & $4(11.1)$ & $4(8.0)$ & $0(0)$ & $3(23.1)$ & $0(0)$ \\
\hline Iru & $11(8.6)$ & $6(4.7)$ & $3(10.7)$ & $1(3.6)$ & $2(5.6)$ & $0(0)$ & $5(10.0)$ & $1(2)$ & $0(0)$ & $0(0)$ \\
\hline$O g i$ & $13(10.2)$ & $8(6.3)$ & $0(0)$ & $0(0)$ & $0(0)$ & $0(0)$ & $3(6.0)$ & $0(0)$ & $0(0)$ & $0(0)$ \\
\hline Кипи & $12(9.4)$ & $4(3.1)$ & $1(3.6)$ & $0(0)$ & $0(0)$ & $0(0)$ & $0(0)$ & $0(0)$ & $0(0)$ & $0(0)$ \\
\hline Kindirmo & $13(10.2)$ & $6(4.7)$ & $6(21.4)$ & $0(0)$ & $7(19.4)$ & $2(5.6)$ & $\begin{array}{l}10(20.0 \\
)\end{array}$ & $1(2.0)$ & $2(15.4)$ & $1(7.7)$ \\
\hline Wara & $7(5.5)$ & $3(2.3)$ & $1(3.6)$ & $0(0)$ & $5(13.9)$ & $3(8.3)$ & $5(10.0)$ & $0(0)$ & $2(15.4)$ & $2(15.4)$ \\
\hline Total & $61(47.7)$ & $28(21.9)$ & $16(57.1)$ & $1(3.6)$ & $25(69.4)$ & $9(25.0)$ & $27(54.0)$ & $2(4.0)$ & $7(53.8)$ & $3(23.1)$ \\
\hline
\end{tabular}


Table 6: Distribution of Hyaluronidase Producing Coagulase-Negative Staphylococci from Fermented Food Samples

\begin{tabular}{lccccc}
\hline & \multicolumn{5}{c}{ CoNS Species } \\
\cline { 2 - 5 } Food Samples & Staphylococcus & Staphylococcus & Staphylococcus & Staphylococcus & Staphylococcus \\
& epidermidis & kloosii & xylosus & simulans & caprae \\
& $\mathbf{1 2 8}(\mathbf{\%})$ & $\mathbf{2 8}(\mathbf{\%})$ & $\mathbf{3 6}^{\mathbf{a}}(\mathbf{\%})$ & $\mathbf{5 0}^{\mathbf{a}}(\mathbf{\%})$ & $\mathbf{1 3}^{\mathbf{a}}(\mathbf{\%})$ \\
\hline Nono & $9(7.0)$ & $4(14.3)$ & $0(0)$ & $8(16.0)$ & $3(23.1)$ \\
Iru & $21(16.4)$ & $1(3.6)$ & $0(0)$ & $6(12.0)$ & $0(0)$ \\
Kuni & $5(3.9)$ & $0(0)$ & $0(0)$ & $2(4.0)$ & $0(0)$ \\
Kindirmo & $4(3.1)$ & $2(7.1)$ & $0(0)$ & $2(4.0)$ & $0(0)$ \\
Wara & $12(9.4)$ & $8(28.6)$ & $9(25)$ & $8(16.0)$ & $2(15.4)$ \\
Total & $5(3.9)$ & $1(3.6)$ & $6(16.7)$ & $5(10.0)$ & $2(15.4)$ \\
\hline
\end{tabular}

a: total number of each CoNS species 
Table 7: Frequency of TSST-1 Phenotype Producing Coagulase-Negative Staphylococci in Fermented Food Samples

\begin{tabular}{lccccc}
\hline \multirow{2}{*}{ Food Samples } & \multicolumn{5}{c}{ CoNS Species } \\
\cline { 2 - 6 } & $\begin{array}{l}\text { Staphylococcus } \\
\text { epidermidis }\end{array}$ & Staphylococcus & Staphylococcus & Staphylococcus & Staphylococcus \\
& $\mathbf{1 2 8}^{\mathbf{a}}(\mathbf{\%})$ & $\mathbf{2 8}^{\mathbf{a}} \mathbf{( \% )}$ & $\mathbf{3 6}^{\mathbf{a}} \mathbf{( \% )}$ & $\mathbf{5 0}^{\mathbf{a}}(\mathbf{\%})$ & $\mathbf{1 3}^{\mathbf{a}} \mathbf{( \% )}$ \\
\hline Nono & $7(5.5)$ & $2(7.1)$ & $4(11.1)$ & $8(16.0)$ & $2(15.4)$ \\
Iru & $10(7.8)$ & $1(3.6)$ & $1(2.8)$ & $4(8.0)$ & $0(0)$ \\
Ogi & $8(6.3)$ & $0(0)$ & $0(0)$ & $1(2.0)$ & $0(0)$ \\
Kunu & $5(3.9)$ & $1(3.6)$ & $0(0)$ & $0(0)$ & $0(0)$ \\
Kindirmo & $14(10.9)$ & $5(17.9)$ & $10(27.8)$ & $8(16)$ & $2(15.4)$ \\
Total & $54(42.2)$ & $11(39.3)$ & $15(41.7)$ & $21(42.0)$ & $4(30.8)$ \\
\hline
\end{tabular}

: total number of each CoNS species 
Table 8: Frequency of Enterotoxin Producing CoNS Species

\begin{tabular}{llllll}
\hline \multirow{2}{*}{$\begin{array}{c}\text { Etaphylococcal } \\
\text { (SEs) }\end{array}$} & $\mathrm{n}=128(\%)$ & $\mathrm{n}=28(\%)$ & $\mathrm{n}=36(\%)$ & $\mathrm{n}=50(\%)$ & $\mathrm{n}=13(\%)$ \\
\cline { 2 - 6 } SEA & $28(21.9)$ & $3(10.7)$ & $16(44.4)$ & $10(20.0)$ & $4(30.8)$ \\
SEB & $2(1.6)$ & $5(17.9)$ & $8(22.2)$ & $4(8.0)$ & $0(0)$ \\
SEC & $4(3.1)$ & $0(0)$ & $3(8.3)$ & $1(2.0)$ & $1(7.7)$ \\
SED & $2(1.6)$ & $0(0)$ & $4(11.1)$ & $2(4.0)$ & $0(0)$ \\
Total & $36(28.1)$ & $8(28.6)$ & $31(86.1)$ & $17(34.0)$ & $5(38.5)$ \\
\hline $\mathrm{n}=$ total number of each CoNS species & & &
\end{tabular}




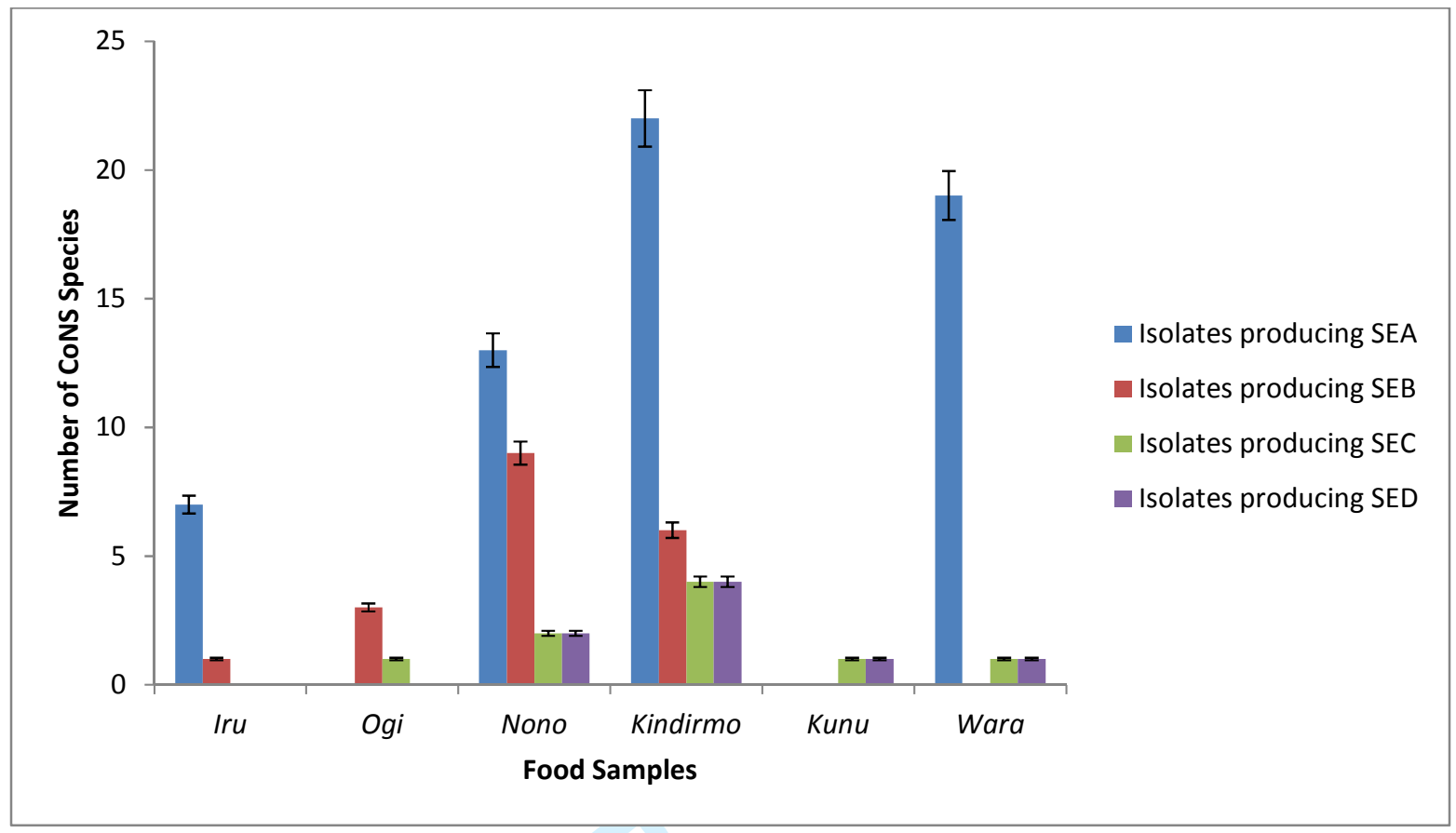

Fig. 1: Number of Enterotoxigenic CoNS Isolates in Fermented Food Samples 